\title{
Enzyme Activity, Glomalin, and Soil Organic Carbon in Agroforestry Systems
}

\author{
Cristiane Figueira da Silva ${ }^{1}$ (D) 0000-0003-4606-3149 \\ Marcos Gervasio Pereira ${ }^{1}$ (D) 0000-0002-1402-3612 \\ João Henrique Gaia Gomes ${ }^{1}$ (1) 0000-0003-3870-7258 \\ Marcelo Antoniol Fontes ${ }^{2}$ (1) 0000-0002-9651-8802 \\ Eliane Maria Ribeiro da Silva ${ }^{2}$ (D) 0000-0002-9180-9870
}

\begin{abstract}
This study aimed to evaluate enzyme activity, glomalin-related soil proteins (GRSP), soil chemical attributes, and total organic carbon (TOC) in two Agroforestry systems (AFS) (AFS-1 and AFS-2), in a traditional agriculture area (TA), and secondary forest (SF) area in Paraty (RJ). Soil samples (from 0 to $5 \mathrm{~cm}$ depth) were collected during the rainy and dry seasons. AFS improves and/or maintains soil chemical indicators based on $\mathrm{pH}$ increase, reduces aluminum saturation and maintains soil nutrient content $(\mathrm{Ca}, \mathrm{Mg}$ and $\mathrm{K})$, when compared with SF. The contribution of organic material and the biodiversity of the AFS provide the maintenance of the total organic carbon content of the soil. AFS maintain the activity of the enzymes protease, $\beta$-glucosidase, acid phosphatase, and total enzyme activity (FDA), and the production of glomalin-related soil protein at levels similar to those observed in SF, especially during the rainy season.
\end{abstract}

Keywords: protease, $\beta$-glucosidase, FDA, acid phosphatase, agroecology.

\section{INTRODUCTION AND OBJECTIVES}

The municipality of Paraty comprises five conservation units of the Brazilian Atlantic Forest, and most rural properties are located within areas surrounding these units. Agricultural development shows a threat to the preservation of these conservation units. Therefore, alternative systems, known as agroforestry systems (AFS), were established in traditional communities surrounding the conservation units in order to restore degraded areas and to generate income (Souza \& Piña Rodrigues, 2013).

AFS are soil management systems that closely resemble the ecology of natural forests and are important for sustainable forest exploitation in humid tropical ecosystems (Gama-Rodrigues et al., 2008). These systems are capable of not only producing at the time of development, but also preserve environmental, economic, and social factors so that the systems may be used by future generations (Oliveira et al., 2010). Given the complexity of the potential AFS benefits, the scientific community has been using indicators of soil quality to show how these systems contribute to soil conservation (Iwata et al., 2012; Lima et al., 2010)

Soil attributes such as enzyme activity, glomalin-related soil protein (GRSP), and soil organic carbon fractions are used as potential indicators of soil quality, since they are directly and/or indirectly related to nutrient cycling, soil fertility, structure, and stability of soil aggregates, as well as to plant productivity (Burns et al., 2013).

Microorganisms are the most important source of enzymes in the soil (Bugg, 2012). These enzymes catalyze reactions that occur during nutrient cycling (Vidican \& Stoian, 2015). Enzyme activity is a good indicator of soil quality and microbial activity because of the direct correlation between soil processes and the dynamics of soil biota, as well as because of the responsiveness of microorganisms to soil management practices and environmental conditions. Vallejo et al. (2010) observed that integrated agroforestry promotes an increase in soil microbial biomass and enzyme activity ( $\beta$-glucosidase, urease, and acid and alkaline phosphatases), creating propitious

\footnotetext{
${ }^{1}$ Universidade Federal Rural do Rio de Janeiro (UFRRJ), Seropédica, RJ, Brasil

${ }^{2}$ Centro Nacional de Pesquisa de Agrobiologia (Embrapa Agrobiologia), Seropédica, RJ, Brasil
} 
conditions for the biogeochemical cycle and providing a favorable microbial habitat.

Glomalin is a glycoprotein produced by arbuscular mycorrhizal fungi (AMF) as a constituent of their hyphal cell wall (Driver et al., 2005), and has a cementing effect upon contact with soil particles (Wright \& Upadhyaya, 1998). Depending on the quantification method (Bradford method) and considering that the specific protein glomalin has not yet been isolated or described (Singh et al., 2013), glomalin is generally quantified from the soil as a glomalin-related soil protein (GRSP) (Rillig, 2004). Abundant in soils, GRSP are strongly correlated with the stability of soil aggregates and constitute a significant portion of terrestrial carbon pools (Singh et al., 2013; Wright et al., 1996). Their role in the formation of soil aggregates has important consequences for carbon storage in the soil (Singh et al., 2013; Wu et al., 2012). GRSP concentrations respond to changes in soil exploitation, as well as to soil management practices. These proteins have been used in environmental monitoring since their presence is a good indicator of soil quality and AMF activity (Islas et al., 2016).

Total organic carbon (TOC) represents approximately $58 \%$ of the soil organic matter (SOM). Because TOC is directly associated with the physical, chemical, and biological characteristics of the soil (Matoso et al., 2012), it is one of the main indicators of soil quality and is also related to soil sustainability and production capacity (Carter, 2002). Several studies have shown the influences of soil management systems on soil TOC content (Silva et al., 2012; Portugal et al., 2008).

Different agricultural management systems may result in changes in soil chemical properties. Understanding soil fertility is one of the key factors for successful agricultural activity, and the assessment of soil chemical attributes under different soil management systems is an important method for evaluating soil quality and identifying medium- and long-term sustainable production systems (Iwata et al., 2012).

This study tested the hypothesis that agroforestry systems maintain and/or increase soil fertility and soil microbiota activity when compared to secondary forests within conservation units of the Brazilian Atlantic Forest. We evaluated enzyme activity, GRSP levels, soil chemical attributes, and soil total organic carbon (TOC) as indicators of soil quality, in two AFS (AFS-1 and AFS-2) and in a traditional agriculture area (TA). A secondary forest area (SF) in the Quilombola community of "Campinho da Independência", Paraty (Rio de Janeiro, RJ), Brazil was used as reference.

\section{MATERIALS AND METHODS}

The study area was located in the Quilombola community of "Campinho da Independência", in the district of Paraty-
Mirim, municipality of Paraty, RJ, Brazil ( $44^{\circ} 42^{\prime} \mathrm{W}, 23^{\circ} 17^{\prime} \mathrm{S}$, $60 \mathrm{~m})$. The community is located in the central part of the environmental protection area of Cairuçu and along the Paraty-Mirim riverbanks and the BR-101 road. The region has a Cwa climate (Köppen, 1938), with moderate temperatures and hot and rainy summers. The native vegetation consists of Submontane Dense Ombrophilous forests (Radam Brasil, 1983).

The study area had four different types of vegetation cover: two 12-year-old agroforestry systems (AFS-1 and AFS-2), each characterized by a different vegetation type; a traditional agriculture area (TA); and a secondary forest area (SF) (Table 1). The AFS (400 $\mathrm{m}^{2}$ of area, each) and the TA (800 $\mathrm{m}^{2}$ of area) are found in the same landscape position, approximately $15 \mathrm{~m}$ from the SF, which features an area of approximately 1 ha. All areas are located in the lower part of the landscape and the soil is classified as Cambissolo Háplico (Inceptisol).

The AFS were established in February 2003 as experimental units $(20 \times 20 \mathrm{~m}$ plots $)$ of Regenerative and Analogous Agroforestry Systems, in order to create sustainable alternatives for income generation in traditional communities. A peach palm (Bactris gasipaes Kuhnt) was used as the main incomegenerating species. Each plant was individually planted (one plantlet per hole), interspaced with leguminous (AFS-1) and non-leguminous species (AFS-2). Due to the forest regeneration processes, the current compositions of these systems differ from the original planting (Table 1). The area occupied by the AFS was previously used for banana (Musa sp.) and cassava (Manihot esculenta) production.

In each study unit, in an area of $400 \mathrm{~m}^{2}$, three individual soil samples $(0-5 \mathrm{~cm}$ depth) were randomly collected in the dry (September 2015) and rainy (March 2016) seasons. These samples were combined to form a composite sample, with a total of four composite soil samples per area. They were dried at room temperature and used to evaluate soil chemical attributes, TOC in the soil and its chemical fractions, enzyme activity in the soil, and to quantify GRSP.

The soil samples were passed through a $2 \mathrm{~mm}$ mesh sieve after air drying, thus obtaining the air-dried fine ground (ADFG). Soil chemical attributes were evaluated according to the method developed by Donagemma et al. (2011): $\mathrm{pH}$ in water; $\mathrm{Al}^{3+}, \mathrm{Ca}^{2+}, \mathrm{Mg}^{2+}$, extracted with $\mathrm{KCl}$ at $1 \mathrm{~mol} \mathrm{~L}^{-1}$, at the ratio $1: 10 ; \mathrm{Al}^{3+}$, by titration with $0.025 \mathrm{~mol} \mathrm{~L}{ }^{-1} \mathrm{NaOH} ; \mathrm{Ca}^{2+}$ and $\mathrm{Mg}^{2+}$, by atomic absorption spectrophotometry; $\mathrm{K}^{+}$and $\mathrm{P}$, by extraction with $\mathrm{Mehlich}^{-1}$ ( $\mathrm{HCl} 0.05 \mathrm{~mol} \mathrm{~L}^{-1}+0.0125 \mathrm{~mol} \mathrm{~L}^{-1} \mathrm{H}_{2} \mathrm{SO}_{4}$ ), at the ratio 1:10; and $\mathrm{H}+\mathrm{Al}$, by $\mathrm{Ca}(\mathrm{OAc})_{2}$ at $0.5 \mathrm{~mol} \mathrm{~L}^{-1}$, adjusted $\mathrm{pH}$ 7.0 , at the ratio $1: 15$, titrated with $0.0606 \mathrm{~mol} \mathrm{~L}^{-1} \mathrm{NaOH}$. Total organic carbon (TOC) $\left(\mathrm{g} \mathrm{kg}^{-1}\right)$ was extracted by wet oxidation with potassium dichromate. TOC in the soil was quantified according to Yeomans \& Bremner (1988). 
Table 1. Species grown in 2013 in agroforestry systems, traditional agriculture and secondary forest located in the community of Campinho da Independência, in the municipality of Paraty, RJ.

\begin{tabular}{cl} 
Areas & \multicolumn{1}{c}{ Plant species } \\
& Agroforestry systems - 1: Ingá (Inga laurina); Embira de sapo (Lochocarpus huilleminianus (Tull.) Malme); Abiu \\
(Pouteria macrophylla Radkl.); Jaca (Artocarpus heterophyllus Lam.); Carambola (Averrhoa carambola L.); Goiaba \\
(Psidium guajava); Graviola (Annona muricata); Guapuruvu (Schizolobium parahyba (vell) Blake); Araribá \\
(Centrolobium tomentosum Guill. Ex Benth.); Jatobá (Hymenaea courbaril L.); Copaíba (Copaíba langsdorffii Desf); \\
Terminalia sp.; Jussara (Euterpe edulis Mart.) \\
Agroforestry systems - 2: Ingá (Inga edulis e Inga laurina); Urucum (Bixa orellana L.); Embira de sapo (Lonchocarpus \\
guilleminianus (Tull). Malme); Pau viola (Cytharexyllum myrianthum Cham); Abiu (Pouteria macrophylla Radkl.); \\
Limão (Citrus sp.); Jaca (Artocarpus heterophyllus Lam.); Carambola (Averrhoa carambola L.); Goiaba (Psidium \\
guajava); Graviola (Annona muricata); Cedro (Cedrela odorata); Canela (Nectandra lanceolata Ness et Mart. ex Nees); \\
Jequitibá (Cariniana legalis (Mart.) Kuntze); Bicuiba (Virola bicuhyba (Schott) Warb.); Clidemia urceolata; Embira de \\
Sapo (Lochocarpus huilleminianus (Tull.) Malme); Miconia calvescens; Piptadenia paniculata; Schinus terebinthifolius; \\
Paineira (Ceiba speciosa); Jussara (Euterpe edulis Mart.) \\
Traditional agriculture: area used the traditional management systems of intercropping, crop rotation, and fallow for \\
crop (maize, bean, yam, and banana) production. No fertilization or burning. \\
Secondary forest: Pau óleo (Alchornea triplinervia Mull. Arg.); urtiga (Boehmeria caudata Sw); embaúba (Cecropia \\
pachystachya Trécul.); camboatá (Cupania oblongifolia Mart.); maria mole (Guapira opposita (Vell.) Reitz); pau de \\
arco (Guarea macrophylla Vahl.); ingá (Inga laurinam); embira de porco (Lonchocarpus guilleminianus (Tul.) Malme); \\
miconia (Miconia calvescens DC.); canela (Nectandra lanceolata Nees and Mart. ex Nees); pariporaba (Piper arboreum \\
Aubl.); angico (Piptadenia paniculata Benth); Psychotria sp; acácia (Senna multijuga (Rich.); joá (Solanum pseudoquina \\
A.S.T.-Hil.); amendoeira da praia (Terminalia sp.); catinguá (Trichilia hirta L.); Vochysia sp.
\end{tabular}

Source: Modified from Tavares et al. (2018).

Enzyme activity was determined by the quantification of $\beta$-glucosidase, acid phosphatase, and protease. In addition, the total enzyme activity was evaluated by analyzing the hydrolysis of fluorescein diacetate (FDA). $\beta$-Glucosidase activity was analyzed according to Tabatabai (1994), using $1.0 \mathrm{~g}$ of soil and the substrate PNG ( $p$-nitrophenyl- $\beta$-dglucoside; $\left.0.05 \mathrm{~mol} \mathrm{~L}^{-1}\right)$. Colorimetry was determined in a spectrophotometer at $410 \mathrm{~nm}$. Results were expressed in $\mu \mathrm{mol} \cdot \mathrm{g}^{-1} \cdot \mathrm{h}^{-1} \mathrm{p}$-nitrophenyl. Acid phosphatase activity was analyzed with $1.0 \mathrm{~g}$ soil, using $p$-nitrophenyl-sulfate (PNS) as a substrate $\left(0.05 \mathrm{~mol} \mathrm{~L}^{-1}\right)$ (Tabatabai, 1994). Colorimetry was determined in a spectrophotometer at $410 \mathrm{~nm}$. Results were expressed in $\mu \mathrm{mol} \cdot \mathrm{g}^{-1} \mathrm{~h}^{-1} p$-nitrophenyl. Protease activity was analyzed using the method of Alef \& Nannipieri (1995), with $1.0 \mathrm{~g}$ soil, $2 \%$ sodium caseinate solution, and Folin-Ciocalteu reagent $(33 \%)$. Results were read in a spectrophotometer at $700 \mathrm{~nm}$. Protease activity was expressed in $\mu \mathrm{g}$ tyrosine $\mathrm{g}^{-1}$ soil $\mathrm{h}^{-1}$. FDA hydrolysis was analyzed according to Schnurer \& Rosswall (1982), using $1.0 \mathrm{~g}$ soil and FDA stock solution. Samples were read in a spectrophotometer at $490 \mathrm{~nm}$ to determinate the amount of hydrolyzed fluorescein. FDA activity was expressed in $\mu$ g fluorescein $\mathrm{g}^{-1}$ soil $\mathrm{h}^{-1}$.

Soil glomalin was quantified as GRSP. Two GRSP fractions (easily extractable glomalin, EE-GRSP; and total glomalin, T-GRSP) were differentiated based on the extraction conditions. EE-GRSP was extracted by autoclavation, using $1.0 \mathrm{~g}$ soil and $8.0 \mathrm{~mL}_{20} \mathrm{mmol} \mathrm{L}^{-1}$ sodium citrate (pH 7.4), at $121^{\circ} \mathrm{C}$ for $30 \mathrm{~min}$. T-GRSP was extracted using $1.0 \mathrm{~g}$ soil and $8.0 \mathrm{~mL}^{2} \mathrm{mmol} \mathrm{L}^{-1}$ sodium citrate ( $\mathrm{pH} 8.0$ ), at $121^{\circ} \mathrm{C}$ for $30 \mathrm{~min}$. T-GRSP was extracted using multiple autoclavation cycles until the samples reached a light-yellow color. After autoclavation, both fractions were subjected to centrifugation at $4,000 \mathrm{rpm}$ for $20 \mathrm{~min}$.; the supernatant was removed for subsequent protein quantification. Glomalin was quantified according to the Bradford method (Wright et al., 1996), available at http://www.usda.gov, using bovine serum albumin (BSA) as standard. For both fractions, glomalin concentrations were corrected for $\mathrm{mg} \mathrm{g}^{-1}$ soil, accounting for the total supernatant volume and the soil dry mass.

Results were tested for normal error distribution (Lillifors test; SAEG 5.0) and homogeneity of variances (Cochran's and Bartlett's tests; SAEG 5.0). Mean values were subsequently compared by applying the Bonferroni t-test, using the statistical software 4.6 Sisvar. Cluster analysis was conducted with the statistical software PAST.

\section{RESULTS AND DISCUSSION}

\subsection{Soil chemical attributes and total organic carbon}

In the dry season, $\mathrm{pH}$ values differed between AFS- 1 and AFS-2, TA, and SF, with SF having the lowest values, followed by AFS- 1 and TA with intermediate values, and AFS- 2 with the highest values (Table 2). In the rainy season, only AFS-2 differed from $\mathrm{SF}$, having the highest $\mathrm{pH}$ values (Table 2), which suggests that AFS, especially AFS-2, could improve soil $\mathrm{pH}$, 
preventing excessive soil acidification. This may be because of the alkaline matter formed during litter decomposition in these systems (Tian et al., 2013). On the other hand, in general, we observed lower $\mathrm{Al}^{3+}$ levels in the AFS and TA than we did in the SF, while $\mathrm{H}+\mathrm{Al}$ concentrations were similar in all areas except for the TA, which had lower levels than the other areas (Table 2). Soil organic matter quality can also explain the low $\mathrm{Al}^{3+}$ value, since it may participate in the complexation of free $\mathrm{Al}^{3+}$, adding bases $\left(\mathrm{Ca}^{2+}, \mathrm{Mg}^{2+}\right.$, and $\left.\mathrm{K}^{+}\right)$, and consequently reducing acidity $\left(\mathrm{Al}^{3+}\right)$ and increasing the pH (Pavinato \& Rosolem, 2008).

$\mathrm{Ca}, \mathrm{Mg}$, and $\mathrm{K}$ levels did not differ between areas in both seasons (Table 2), suggesting that different vegetation covers (AFS- 1 and AFS-2) and fallows (TA) favor the inputs of these macronutrients in the soil. Variation in vegetation cover, and the associated management, contributed to deposition of plant material (roots, twigs, and leaves), which, upon mineralization, influences chemical reactions in the soil, resulting in maintenance fertility and soil quality (Souza et al., 2012), when compared to the secondary forest. However, $\mathrm{P}$ levels were higher in the SF than in the AFS and the TA (Table 2).

In this study, we observed that, in general, there were no significant changes in TOC levels, in both seasons, when AFS areas were compared with a secondary forest (Table 3). Similar TOC levels between AFS and SF areas may be associated with comparable inputs of organic material in both areas and seasons. According to Gama-Rodrigues et al. (2008), the structure of AFS might be very similar to the structure of native vegetation. In addition, the type of management adopted in AFS (based on the diversity of plant species, which provide soil cover through dense layer deposition of organic material, continuously generated by the fall of leaves and branches of different crops) optimizes nutrient and carbon cycling processes. Such scenario would promote aggregate stabilization and raise the levels of organic matter due to exudate release and the rapid formation, death, and decomposition of fine roots favored by the biochemical cycling (Brown et al., 2006).

The TA area did not differ in the TOC contents in relation to the other areas (AFS and SF), in the dry season. In contrast, in the rainy season, it showed the lowest TOC levels. This could be explained by the fact that, in the rainy season, TOC input and output in the TA area did not occur at the same magnitude as in the other systems, in contrast to what occurred during the dry season. In the dry season, the TA area was fallow for about three years, and covered by undergrowth, which may have allowed lower organic matter losses in the soil and, consequently, a greater incorporation of TOC. On the other hand, in the rainy season, this area was being cultivated for six months with a yam culture. Thus, possible changes in temperature, humidity, aeration, absorption and leaching in the soil as a consequence of cultivation (Sanchez, 1976) may have accelerated the TOC mineralization process (Cerri et al., 1985). That is, this possibly affected soil carbon levels due to changes in the input of vegetable residues and in the rate of soil OM decomposition, leading to a greater amplitude between the values observed in the TA area and in the other areas (AFS and $\mathrm{SF}$ ), allowing differences to be detected in the rainy season.

Table 2. Soil chemical attributes in areas of secondary forest (SF), agroforestry systems (AFS-1 and AFS-2), and traditional agriculture (TA), at a depth of $0-5 \mathrm{~cm}$, during the dry and rainy seasons.

\begin{tabular}{|c|c|c|c|c|c|c|c|c|}
\hline \multirow{3}{*}{ Areas } & \multicolumn{2}{|c|}{ pH } & \multicolumn{2}{|c|}{$\mathrm{Al}^{3+}$} & \multicolumn{2}{|c|}{$\mathrm{H}+\mathrm{Al}$} & \multicolumn{2}{|c|}{$\mathrm{Ca}^{2+}$} \\
\hline & & & \multicolumn{6}{|c|}{$\mathrm{cmol}_{\mathrm{c}} \mathrm{dm}^{-3}$} \\
\hline & Dry & Rainy & Dry & Rainy & Dry & Rainy & Dry & Rainy \\
\hline SF & $4.31 \mathrm{c}$ & $4.33 b$ & $1.39 \mathrm{a}$ & $1.38 \mathrm{a}$ & $1.89 \mathrm{a}$ & $2.51 \mathrm{a}^{*}$ & $1.19^{\mathrm{a}}$ & $1.15 \mathrm{a}$ \\
\hline AFS-1 & $4.55 b$ & $4.77 \mathrm{ab}$ & $1.07 \mathrm{ab}$ & $0.81 \mathrm{ab}$ & $1.93 \mathrm{a}$ & $2.38 \mathrm{ab}^{\star}$ & $1.42^{\mathrm{a}}$ & $1.38 \mathrm{a}$ \\
\hline AFS-2 & $5.11 \mathrm{a}$ & $5.01 \mathrm{a}$ & $0.60 \mathrm{~b}$ & $0.68 b$ & $1.82 \mathrm{a}$ & $2.35 \mathrm{ab}^{\star}$ & $1.46^{\mathrm{a}}$ & $1.46 \mathrm{a}$ \\
\hline TA & $4.79 b$ & $4.70 \mathrm{ab}$ & $0.59 \mathrm{~b}$ & $1.09 \mathrm{ab}$ & $1.51 \mathrm{a}$ & $2.09 b^{\star}$ & $1.49^{\mathrm{a}}$ & $1.36 \mathrm{a}$ \\
\hline \multirow{3}{*}{ Areas } & \multicolumn{2}{|c|}{$\mathrm{Mg}^{2+}$} & \multicolumn{2}{|c|}{$\mathbf{K}^{+}$} & \multicolumn{2}{|c|}{$\mathbf{P}$} & \multicolumn{2}{|c|}{ TOC } \\
\hline & \multicolumn{4}{|c|}{$\mathrm{cmol}_{\mathrm{c}} \mathrm{dm}^{-3}$} & \multicolumn{2}{|c|}{$\mathrm{mg} \mathrm{dm}^{-3}$} & \multicolumn{2}{|c|}{$\mathrm{g} \mathrm{kg}^{-1}$} \\
\hline & Dry & Rainy & Dry & Rainy & Dry & Rainy & Dry & Rainy \\
\hline SF & $0.58 \mathrm{a}$ & $0.58 \mathrm{a}$ & $0.019 \mathrm{a}$ & $0.019 a$ & $18.22 \mathrm{a}$ & $21.00 \mathrm{a}$ & $15.28 \mathrm{ab}^{*}$ & $10.65 a$ \\
\hline AFS-1 & $0.43 a$ & $0.53 a$ & $0.018 \mathrm{a}$ & $0.022 \mathrm{a}$ & $3.50 \mathrm{~b}$ & $3.22 \mathrm{~b}$ & $18.49 \mathrm{a}^{*}$ & $9.18 \mathrm{a}$ \\
\hline AFS-2 & $0.62 \mathrm{a}$ & $0.58 \mathrm{a}$ & $0.018 \mathrm{a}$ & $0.017 \mathrm{a}$ & $2.89 \mathrm{~b}$ & $2.53 b$ & $11.15 \mathrm{~b}$ & $8.67 \mathrm{a}$ \\
\hline TA & $0.47 \mathrm{a}$ & $0.48 \mathrm{a}$ & $0.020 \mathrm{a}$ & $0.021 \mathrm{a}$ & $3.47 \mathrm{~b}$ & $3.41 \mathrm{~b}$ & $17.35 \mathrm{a}^{\star}$ & $4.83 \mathrm{~b}$ \\
\hline
\end{tabular}

Mean values followed by the same letter in the same column did not differ according to the Bonferroni t-test at a $5 \%$ significance level. TOC: total organic carbon. ${ }^{\star}$ Indicates a significant difference between seasons, according to the Bonferroni t-test at a 5\% significance level. 
TOC levels were higher in the dry season than they were in the rainy season (Table 2), possibly because of the increased deposition of leaf litter and death of fine roots $(\varnothing<2 \mathrm{~mm})$ during the dry period, in the SF and AFS. This fact may have stimulated soil microbiota activity, promoting higher rates of leaf litter decomposition and greater carbon uptake into the soil. When evaluating the amount of litter in the AFS and in the SF in the same region analyzed in our study, Souza et al. (2016) observed that deposition rates were higher at the end of the dry period than they were in the rainy period. Leaf litter and fine roots constituted the main sources of carbon input in the soil (Salcedo \& Sampaio, 2008). In the case of TA, soil tillage, which had been fallow for three years in the dry season, for yam cultivation in the rainy season, may have resulted in higher rates of carbon mineralization, as well as the lower input of organic matter in the system.

\subsection{Soil enzyme activity}

In the dry season, acid phosphatase activity was lower in the AFS and TA soils than it was in the SF. In the rainy season, this activity did not vary between AFS and SF (Table 3). Microorganisms and plant roots are the primary factors responsible for acid phosphatase synthesis (Tabatabai, 1994). It is possible that the presumed higher plant diversity (Table 1) in the secondary forest area resulted in a more developed root system and intense biological activity; this could explain the higher phosphatase activity compared to the TA. Composition of plant species may also be a factor to be considered to explain the variation in acid phosphatase enzyme activity in the soil between the studied areas (Li et al., 2004). Vegetation might affect phosphatase activity due to three factors: enzyme production by the plants, promotion of microbial activity in the soil, and deposition of plant residues, which increase SOM levels (Fernandes et al., 1998). In addition to favoring microbial activity, SOM protects acid phosphatase from degradation (Harrison, 1983). Rojo et al. (1990) observed higher acid phosphatase activity in acidic soils; this could explain the elevated activity of this enzyme in the SF area, which had low $\mathrm{pH}$ values.

$\beta$-Glucosidase activity differed only in the dry season, having higher values in the SF and in the TA than in the AFS. In the rainy season, there were no differences in $\beta$-glucosidase activity between areas. This pattern was also observed for protease and for the total enzyme activity (evaluated by FDA hydrolysis) in both seasons (except for FDA in AFS-2, which had the lowest values of all the areas). Most of the biochemical reactions that occur in the soil depend on, or are associated with, enzyme activities. The permanent vegetation cover in the SF and AFS provided continuous protection to the soil and a considerable source of nutrients, mostly originating from residues. The effects of vegetation cover on the microbial community may interact with the effects of humidity and temperature fluctuations throughout the year, and therefore affect these populations with varying intensity levels (Stieven et al., 2014).

Table 3. Soil enzyme activity in agroforestry systems (AFS-1 and AFS-2), traditional agriculture (TA) and in secondary forests (SF), at a depth of $0-5 \mathrm{~cm}$, during the dry and rainy seasons.

\begin{tabular}{|c|c|c|c|c|}
\hline \multirow{3}{*}{ Areas } & \multicolumn{2}{|c|}{ Acid phosphatase } & \multicolumn{2}{|c|}{$\beta$-glucosidase } \\
\hline & \multicolumn{4}{|c|}{$\mu \mathrm{mol} \mathrm{g}{ }^{-1}$ soil h $^{-1} p$-nitrofenol } \\
\hline & Dry & Rainy & Dry & Rainy \\
\hline SF & $7.96 \mathrm{a}^{*}$ & $5.95 \mathrm{a}$ & $10.97 \mathrm{a}^{*}$ & $6.97 \mathrm{a}$ \\
\hline AFS-1 & $6.25 b^{*}$ & $4.73 \mathrm{ab}$ & $6.88 \mathrm{~b}^{\star}$ & $5.44 \mathrm{a}$ \\
\hline AFS-2 & $5.73 \mathrm{~b}^{*}$ & $4.66 \mathrm{ab}$ & $7.63 \mathrm{~b}^{*}$ & $6.07 \mathrm{a}$ \\
\hline TA & $6.04 \mathrm{~b}^{*}$ & $4.40 \mathrm{~b}$ & $10.74 \mathrm{a}^{*}$ & $6.34 \mathrm{a}$ \\
\hline \multirow{3}{*}{ Areas } & \multicolumn{2}{|c|}{ Protease } & \multicolumn{2}{|c|}{ FDA } \\
\hline & \multicolumn{2}{|c|}{$\mu g$ tyrosine $\mathrm{g}^{-1}$ soil $^{-1}$} & \multicolumn{2}{|c|}{$\mu \mathrm{g}$ fluorescein $\mathrm{g}^{-1}$ soil $^{-1}$} \\
\hline & Dry & Rainy & Dry & Rainy \\
\hline SF & $482.79 \mathrm{a}$ & $758.72 \mathrm{a}^{*}$ & $144.83 \mathrm{a}$ & $146.45 \mathrm{a}$ \\
\hline AFS-1 & 402.39 a & $682.58 a^{*}$ & $134.76 \mathrm{a}$ & 138.78 a \\
\hline AFS-2 & $519.62 \mathrm{a}$ & $779.82 \mathrm{a}^{*}$ & $112.31 \mathrm{~b}$ & $123.74 b^{*}$ \\
\hline TA & $516.24 \mathrm{a}$ & $725.91 \mathrm{a}$ & $143.81 \mathrm{a}$ & $136.16 \mathrm{ab}$ \\
\hline
\end{tabular}

Mean values followed by the same letter did not differ according to the Bonferroni t-test at a 5\% significance level; FDA: fluorescein diacetate hydrolysis.

* Indicates a significant difference between seasons, according to the Bonferroni t-test at a 5\% significance level. 
Acid phosphatase and $\beta$-glucosidase activities were higher in the dry season than they were in the rainy season, probably because of the higher rates of leaf-litter deposition in the dry period, promoting enzyme activity and resulting in increased carbon incorporation into the soil (Table 3). $\beta$-Glucosidase participates in the final step of cellulose decomposition, in the hydrolysis of the cellobiose residues (Tabatabai, 1994). Some studies (Louzada et al., 1995; Machado et al., 2015; Portela \& Santos, 2007) conducted in an environment of Atlantic Forest reported higher litter depositions in the dry season. High litter inputs in agroforestry systems contribute to soil microbial activity (Costa et al., 2017). In contrast, protease (in the SF, AFS-1, and TA) and FDA (in AFS-2) had higher activity in these areas during the rainy season than during the dry season. This fact may indicate lower levels of $\mathrm{N}$ and $\mathrm{C}$ in the soil in the rainy season, which may have stimulated higher protease activity. According to Geisseler \& Horwath (2008), the activity of the soil protease is interconnected with the availability of carbon and nitrogen. These authors evaluated the regulation of extracellular protease activity in soil in response to different sources and concentrations of nitrogen and carbon, and observed that the reduction in $\mathrm{N}$ and carbon concentrations increases the activity of this enzyme.

\subsection{Glomalin-related soil protein}

In both seasons, the levels of T-GRSP and EE-GRSP in both the AFS were not significantly different from the levels found in the SF (Table 4). According to Oliveira et al. (2009), these proteins contribute to soil aggregation and stability, and, by participating in the carbon cycling, play an important role for the soil microbiota. It is estimated that GRSP contributes to $37 \%$ of the carbon in tropical soils, constituting $3 \%$ of carbon pools in the soil (Lovelock et al., 2004; Schindler et al., 2007).
T-GRSP levels were lower in the TA area than they were in the AFS and SF areas, in both the dry and rainy seasons. However, the amounts of EE-GRSP did not differ between these regions (Table 4), indicating that the fraction that was recently deposited (EE-GRSP) and had not yet been subjected to soil biochemical reactions (Wright et al., 1996) was being synthesized and deposited in the TA area with the same intensity observed in perennial systems (AFS and SF). In contrast, T-GRSP, which represents the fraction that undergoes biochemical reactions and is more intrinsically bound to soil particles, and consequently more recalcitrant (Koide \& Peoples, 2013), was affected by the TA management system. TA management prevents T-GRSP accumulation, unlike the practices adopted in the AFS and in the SF. This suggests that areas with arboreous elements and greater biodiversity promote biochemical transformations and glomalin incorporation into the soil. According to Bird et al. (2002), soils protected by trees accumulate more organic matter and are less exposed to disturbances, a scenario that provides conditions conducive to fungal growth and glomalin synthesis. Higher T-GRSP levels in the forest area than those in the TA may be associated with the temporal accumulation of this protein. Silva et al. (2016) showed that GRSP levels are higher in secondary forest areas than in crop areas. It is not yet clear which factors control the production of GRSP in the environment. Guo et al. (2012) and Wilson et al. (2009) proposed that nutrient availability, organic carbon, climate, litter quality and quantity and AMF diversity, as well as their host and their productivity might affect the amount of GRSP in the soil.

GRSP levels were higher in the rainy season than they were in the dry season. This may be associated with the promotion of higher rates of decomposition of arbuscular mycorrhizal fungi hyphae (structure which shows glomalin in its composition) by the soil biota, with consequent GRSP release (Driver et al., 2005), a process that is normally stimulated by the increased soil moisture during the rainy season.

Table 4. Glomalin-related soil protein in a secondary forest (SF), agroforestry systems (AFS-1 and AFS-2), and traditional agriculture (TA) areas, at a depth of $0-5 \mathrm{~cm}$, in the dry and rainy seasons. T-GRSP: total GRSP; EE-GRSP: easily extractable GRSP.

\begin{tabular}{|c|c|c|c|c|}
\hline \multirow{3}{*}{ Areas } & \multicolumn{2}{|c|}{ T-GRSP } & \multicolumn{2}{|c|}{ EE-GRSP } \\
\hline & \multicolumn{4}{|c|}{$\mathrm{mg} \mathrm{g}^{-1}$ solo } \\
\hline & Dry & Rainy & Dry & Rainy \\
\hline SF & $7.35 \mathrm{a}$ & $18.54 \mathrm{a}^{\star}$ & $0.88 \mathrm{ab}$ & $1.67 \mathrm{a}^{\star}$ \\
\hline AFS-1 & $6.87 \mathrm{a}$ & $11.67 \mathrm{ab}^{*}$ & $1.15 \mathrm{a}$ & $2.58 \mathrm{a}^{*}$ \\
\hline AFS-2 & $6.15 \mathrm{a}$ & $19.01 \mathrm{a}^{*}$ & $0.56 \mathrm{~b}$ & $0.78 \mathrm{a}$ \\
\hline TA & $4.80 \mathrm{~b}$ & $9.50 \mathrm{~b}^{*}$ & $1.32 \mathrm{a}$ & $2.18 \mathrm{a}^{*}$ \\
\hline
\end{tabular}

Mean values followed by the same letter did not differ according to the Bonferroni t-test at a $5 \%$ significance level.

* Indicates a significant difference between seasons, according to the Bonferroni t-test at a 5\% significance level. 

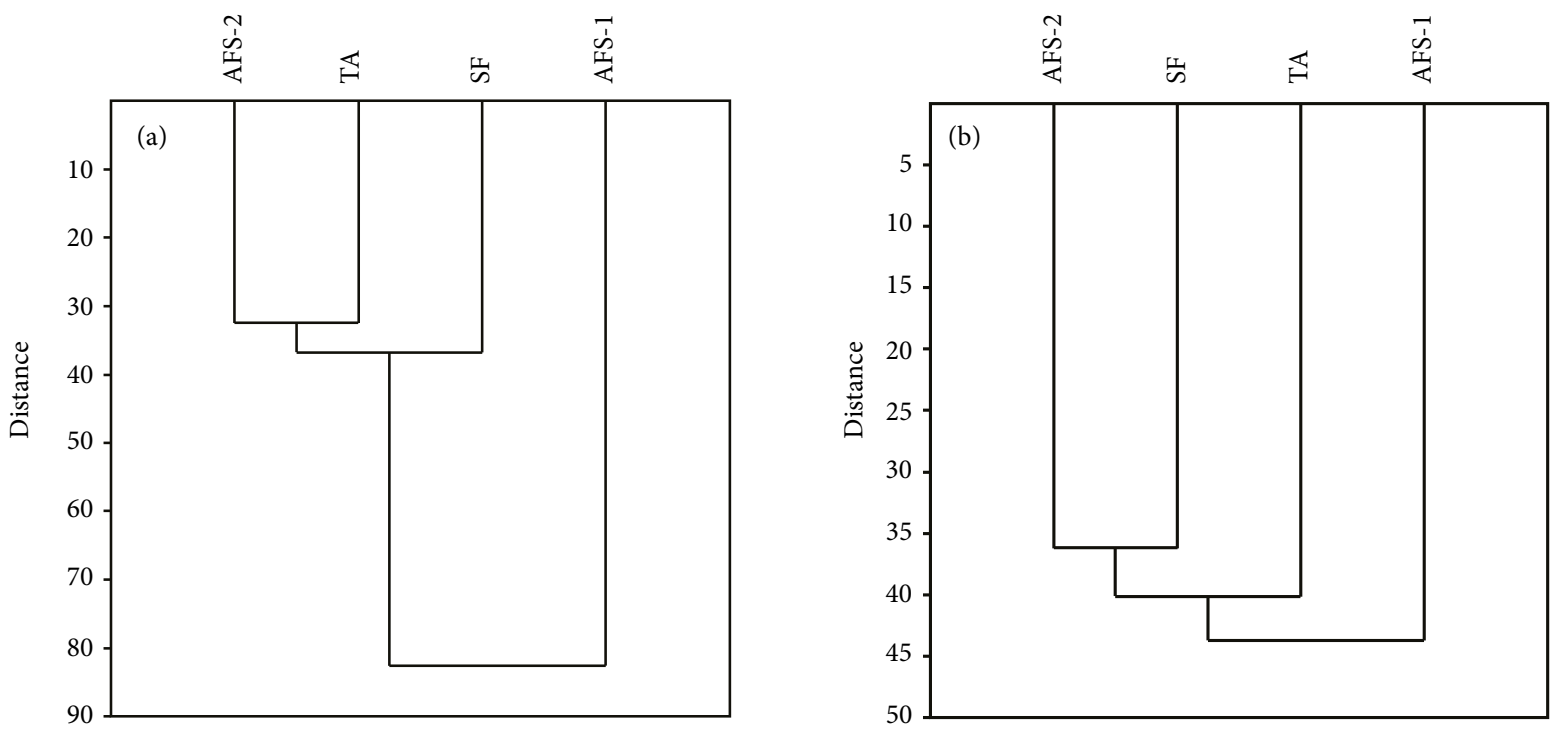

Figure 1. Cluster analysis using the Euclidean distance method for soil chemical and microbiological characteristics in areas of secondary forest (SF), agroforestry (AFS-1 and AFS-2), and traditional agriculture (TA), during the dry (a) and rainy seasons (b) in the municipality of Paraty, RJ.

\subsection{Cluster analysis}

Figure 1 shows the degree of similarity between the chemical, microbiological, and total soil organic carbon in the study areas during the dry (Figure 1a) and rainy (Figure 1b) seasons. In both seasons, the AFS and TA had a similarity of more than $50 \%$ to the SF. However, AFS-1 in the dry season was only $10 \%$ similar to the SF.

The use of AFS near the SF, both surrounding the TA area, has contributed to the formation of an interesting agroecosystem, in which regions with more arboreous elements and greater biodiversity (AFS and SF) protect the TA areas. Previous studies (Phalan, Balmford et al., 2011; Phalan, Onial et al., 2011) have analyzed the combined use of agricultural systems that exploit the soil with different intensities. This combined use enables the formation of many interactions, and a few authors (Phalan, Balmford et al., 2011; Phalan, Onial et al., 2011) claimed that it contributed to the development of more sustainable agroecosystems. These interactions include improvements in the physical, chemical, and biological attributes of the soil (Souza et al., 2012).

\section{CONCLUSIONS}

Agroforestry systems promote improvement and/or maintenance of soil chemical indicators based on $\mathrm{pH}$ increase, reduction of aluminum saturation and maintenance of soil nutrient content ( $\mathrm{Ca}, \mathrm{Mg}$ and $\mathrm{K}$ ).
The contribution of organic material and the biodiversity of the agroforestry systems provide the maintenance of the total organic carbon content of the soil, which may ensure a longer permanence of this material and greater beneficial effects promoted by the organic matter of the soil.

Agroforestry systems maintain the activity of the enzymes protease, $\beta$-glucosidase, acid phosphatase, and total enzyme activity (FDA), and the production of glomalin-related soil protein at levels similar to those observed in a secondary forest, especially during the rainy season. This indicates that agroforestry systems preserve certain soil chemical and biological properties.

\section{SUBMISSION STATUS}

Received: 23 June 2017

Accepted: 10 Mar. 2019

Associate editor: Eduardo Vinicius da Silva

(D) 0000-0002-1115-0624

\section{CORRESPONDENCE TO}

\section{Marcos Gervasio Pereira}

Universidade Federal Rural do Rio de Janeiro, BR 465, km 7, CEP

23890-000, Seropédica, RJ, Brasil

e-mail: mgervasiopereira01@gmail.com

\section{FINANCIAL SUPPORT}

This study was financed by the Coordenação de Aperfeiçoamento de Pessoal de Nível Superior (Capes, finance code 001) and 
Fundação de Amparo à Pesquisa do Estado do Rio de Janeiro (Faperj, Award Number: E26/010.001974/2014).

\section{REFERENCES}

Alef K, Nannipieri P. Protease activities. In: Alef K, Nannipieri P, editores. Methods in applied soil microbiology and biochemistry. New York: Academic Press; 1995. p. 313-315

Bird SB, Herricka JE, Wanderb MM, Wright CSF. Spatial heterogeneity of aggregate stability and soil carbon in Semi-Arid rangeland. Environmental Pollution 2002; 116(3): 445-455. 10.1016/ S0269-7491(01)00222-6

Brown GG, Römbke J, Höfer H, Verhaagh M, Sautter KD, Santana DLQ. Biodiversity and function of soil animals in Brazilian agroforestry systems. In: Gama-Rodrigues AC, Barros NF, GamaRodrigues AF, editores. Sistemas agroflorestais: bases científicas para o desenvolvimento sustentável. Campos dos Goytacazes: Universidade Estadual do Norte Fluminense Darcy Ribeiro; 2006. p. 217-242.

Bugg TDH. Introduction to enzyme and coenzyme chemistry. $3 \mathrm{rd}$ ed. New Jersey: Wiley Blackwell; 2012.

Burns RG, Forest JL, Marxsen J, Sinsabaugh RL, Stromberger ME, Wallenstein MD et al. Soil enzymes in a changing environment: current knowledge and future directions. Soil Biology and Biochemistry 2013; 58: 216-234. 10.1016/j.soilbio.2012.11.009

Carter MR. Soil quality for sustainable land management: organic matter and aggregation interactions that maintain soil functions. Agronomy Journal 2002; 94(1): 38-47. 10.2134/agronj2002.3800

Cerri CC, Feller C, Balesdent J, Victoria RL, Plenecassagne A. Application du tragage isotopique natural en ${ }^{13} \mathrm{C}$ à létude de la dynamique de la matière organique dans les sols. Comptes rendus des séances de l'Académie des Sciences 1985; 300(9): 423-428.

Costa PMO, Araújo MAG, Souza-Motta CM, Malosso E. Dynamics of leaf litter and soil respiration in a complex multistrata agroforestry system, Pernambuco, Brazil. Environment, Development and Sustainability 2017; 19(4): 1189-1203. 10.1007/s10668-016-9789-4

Donagemma GK, Campos DVB, Calderano SB, Teixeira WG, Viana JHM, organizadores. Manual de métodos de análise de solos. 2nd ed. Rio de Janeiro: Embrapa Solos; 2011.

Driver JD, Holben WE, Rillig MC. Characterization of glomalin as a hyphal wall component of arbuscular mycorrhizal fungi. Soil Biology and Biochemistry 2005; 37(1): 101-106. 10.1016/j.soilbio.2004.06.011

Fernandes MF, Anjos JL, Sobral LF, Fernandes RPM, Araújo AS. Efeito da saturação por bases sobre a atividade de fosfatases em um solo de tabuleiro costeiro cultivado com citros. I. Correlações entre a atividade enzimática e as diferentes características do solo alteradas pela calagem. Revista Brasileira de Ciência do Solo 1998; 22(3): 395-401. 10.1590/S0100-06831998000300004

Gama-Rodrigues AC, Gama-Rodrigues EF, Barros NF. Balanço de carbono e nutrientes em plantio puro e misto de espécies florestais nativas no sudeste da Bahia. Revista Brasileira de Ciência do Solo 2008; 32(3): 1165-1179. 10.1590/S0100-06832008000300025

Geisseler D, Horwath RW. Regulation of extracellular protease activity in soil in response to different sources and concentrations of nitrogen and carbon. Soil Biology and Biochemistry 2008; 40(12): 3040-3048. 10.1016/j.soilbio.2008.09.001
Guo H, He XL, Li YP. Spatial distribution of arbuscular mycorrhiza and glomalin in the rhizosphere of Caragana korshinskii Kom. in the Otindag sandy land, China. African Journal of Microbiology Research 2012; 6(28): 5745-5753. 10.5897/AJMR11.1560

Harrison AF. Relations between intensity of phosphatase activity and physico-chemical properties in woodland soils. Soil Biology and Biochemistry 1983; 15(1): 93-99. 10.1016/0038-0717(83)90124-4

Islas AJT, Guijarro KH, Eyherabide M, Rozas HRS, Echeverría HE, Covacevich F. Can soil properties and agricultural land use affect arbuscular mycorrhizal fungal communities indigenous from the Argentinean Pampa soil. Applied Soil Ecology 2016; 101: 47-56. 10.1016/j.apsoil.2016.01.005

Iwata BF, Leite LFC, Araújo ASF, Nunes APL, Gehring C, Campos LP. Sistemas agroflorestais e seus efeitos sobre os atributos químicos em Argissolo Vermelho-Amarelo do Cerrado piauiense. Revista Brasileira de Engenharia Agrícola e Ambiental 2012; 16(7): 730-738.

Koide RT, Peoples MS. Behaviour of bradford-reactive substances is consistent with predictions for glomalin. Applied Soil Ecology 2013; 63(1): 8-14. 10.1016/j.apsoil.2012.09.015

Köppen W. Das geographische system der klimate. Handbuch der klimatologie. Berlim: Borhtraeger; 1938.

Li SM, Li L, Zhang FS, Tang C. Acid phosphatase role in chickpea/ maize intercropping. Annals of Botany 2004; 94(2): 297-303. 10.1093/ aob/mch 140

Lima SS, Aquino AM, Leite LFC, Velásquez E, Lavelle P. Relação entre macrofauna edáfica e atributos químicos do solo em diferentes agroecossistemas. Pesquisa Agropecuária Brasileira 2010; 45(3): 322-331. 10.1590/S0100-204X2010000300013

Louzada MAP, Quintela MFS, Penna LPS. Estudo comparativo da produção de serapilheira em áreas de Mata Atlântica: a floresta secundária "antiga" e uma floresta secundária (capoeira). Oecologia Brasiliensis 1995; 1: 61-74.

Lovelock CE, Wright SF, Nichols KA. Using glomalin as an indicator for arbuscular mycorrhizal hyphal growth: An example from a tropical rain forest soil. Soil Biology and Biochemistry 2004; 36(6): 1009-1012. 10.1016/j.soilbio.2004.02.010

Machado DL, Pereira MG, Correia MEF, Diniz ARD, Santos LL, Menezes CEG. Ciclagem de nutrientes em diferentes estágios sucessionais da Mata Atlântica na bacia do rio Paraíba do Sul, RJ. Bioscience Journal 2015; 31(4): 1222-1237. 10.14393/BJ-v31n1a2015-23092

Matoso SCG, Silva AN, Fiorelli-Pereira EC, Colleta QP, Maia E. Frações de carbono e nitrogênio de um Latossolo Vermelho-Amarelo distrófico sob diferentes usos na Amazônia brasileira. Acta Amazonica 2012; 42(2): 231-240. 10.1590/S0044-59672012000200008

Oliveira JRG, Souza RG, Silva FSB, Mendes ASM, Yano-Melo AM. O papel da comunidade de fungos micorrízicos arbusculares (FMA) autóctones no desenvolvimento de espécies vegetais nativas em área de dunas de restinga revegetadas no litoral do Estado da Paraíba. Revista Brasileira de Botânica 2009; 32(4): 663-670. 10.1590/s0100-84042009000400005

Oliveira NL, Jacq C, Dolci M, Delahaye F. Desenvolvimento sustentável e sistemas agroflorestais na Amazônia mato-grossense. Confins 2010; 10: 1-21. 10.4000/confins.6778 
Pavinato PC, Rosolem CA. Disponibilidade de nutrientes no solo: decomposição e liberação de compostos orgânicos de resíduos vegetais. Revista Brasileira de Ciência do Solo 2008; 32(3): 911-920. 10.1590/S0100-06832008000300001

Phalan B, Balmford A, Green RE, Scharlemann JPW. Minimising the harm to biodiversity of producing more food globally. Food Policy 2011a; 36(1): S62-S71. 10.1016/j.foodpol.2010.11.008

Phalan B, Onial M, Balmford A, Green RE. Reconciling food production and biodiversity conservation: land sharing and land sparing compared. Science 2011b; 333(6047): 1289-1291. 10.1126/science.1208742

Portela RCQ, Santos FAM. Produção e espessura da serapilheira na borda e interior de fragmentos florestais de Mata Atlântica de diferentes tamanhos. Revista Brasileira de Botânica 2007; 30(2): 271-280. 10.1590/S0100-84042007000200011

Portugal AF, Jucksch I, Schaefer CEGR, Wendling B. Determinação de estoques totais de carbono e nitrogênio e suas frações em sistemas agrícolas implantados em Argissolo Vermelho-Amarelo. Revista Brasileira de Ciência do Solo 2008; 32(5): 2091-2100. 10.1590/S0100-06832008000500030

Radam Brasil. Rio de Janeiro: IBGE; 1983. (Levantamento de recursos naturais, 32$) .780 \mathrm{p}$.

Rillig MC. Arbuscular mycorrhizae, glomalin, and soil aggregation. Canadian Journal of Soil Science 2004; 84(4): 355-363. 10.4141/S04-003

Rojo MJ, Carcedo SG, Mateos MP. Distribution and characterization of phosphatase and organic phosphorus in soil fractions. Soil Biology and Biochemistry 1990; 22(2): 169-174. 10.1016/0038-0717(90)90082-B

Salcedo IH, Sampaio EVSB. Matéria orgânica do solo no bioma caatinga. In: Santos GS, Silva LS, Canellas LP, Camargo FAO, editores. Fundamentos da matéria orgânica do solo: Ecossistemas tropicais e subtropicais. Porto Alegre: Metrópole; 2008. p. 419-441.

Sanchez PA. Properties and management of soils in the tropics. Soil Science 1977; 124(3): 187. 10.1097/00010694-197709000-00012

Schnurer J, Rosswall T. Fluorescein diacetate hydrolysis as a measure of total microbial activity in soil and litter. Applied and Environmental Microbiology 1982; 43(6): 1256-1261.

Silva CF, Pereira MG, Miguel DL, Feitora JCF, Loss A, Menezes $\mathrm{CEG}$ et al. Carbono orgânico total, biomassa microbiana e atividade enzimática do solo de áreas agrícolas, florestais e pastagem no médio vale do Paraíba do Sul (RJ). Revista Brasileira de Ciência do Solo 2012; 36(6): 1680-1689. 10.1590/S0100-06832012000600002

Silva CF, Pereira MG, Santos VL, Miguel DL, Silva EMR. Fungos micorrízicos arbusculares: composição, comprimento de micélio extrarradicular e glomalina em áreas de Mata Atlântica, Rio de Janeiro. Ciência Florestal 2016; 26(2): 419-433. 10.5902/1980509822743

Singh PK, Singh M, Tripathi BN. Glomalin: an arbuscular mycorrhizal fungal protein. Protoplasma 2013; 250(3): 663-669. 10.1007/ s00709-012-0453-Z

Souza HN, Goedea RGM, Brussaarda L, Cardoso IM, Duarte EMG, Fernandes RBA et al. Protective shade, tree diversity and soil properties in coffee agroforestry systems in the Atlantic Rainforest biome. Agriculture Ecosystems Environmental 2012; 146(1): 179-196. 10.1016/j.agee.2011.11.007
Souza MCS, Piña-Rodrigues FCM, Casagrande JC, Silva SF, Scoriza $\mathrm{RN}$. Funcionalidade ecológica de sistemas agroflorestais biodiversos: uso da serapilheira como indicador da recuperação de áreas de preservação permanente. Floresta 2016; 46(1): 75-82. 10.5380/ rf.v46i1.34991

Souza MCS, Piña-Rodrigues FCM. Desenvolvimento de espécies arbóreas em sistemas agroflorestais para recuperação de áreas degradadas na floresta ombrófila densa, Paraty, RJ. Revista Árvore 2013; 37(1): 89-98. 10.1590/S0100-67622013000100010

Schindler FV, Mercer ER, Rice JA. Chemical characteristics of glomalin-related soil protein (GRSP) extracted from soils of varying organic matter content. Soil Biology and Biochemistry 2007; 39(1): 320-329. 10.1016/j.soilbio.2006.08.017

Stieven AC, Oliveira DA, Santos JO, Wruck FJ, Campos DTS. Impacts of integrated crop-livestock-forest on microbiological indicators of soil. Agrária - Revista Brasileira de Ciências Agrárias 2014; 9(1): 53-58. 10.5039/agraria.v9ila3525

Tabatabai MA. Soil enzymes. In: Weaver RW, editor. Methods of soil analysis: microbiological and biochemical properties. Madison: Soil Science Society of America; 1994. p. 775-833.

Tavares PD, Silva, CF, Pereira MG, Freo VA, Bieluczyk W, Silva EMR. Soil quality under agroforestry systems and traditional agriculture in the Atlantic Forest biome. Revista Caatinga 2018; 31(4): 954-962. 10.1590/1983-21252018v31n418rc

Tian Y, Cao F, Wang G. Soil microbiological properties and enzyme activity in Ginkgo-tea agroforestry compared with monoculture. Agroforest Systems 2013; 87(5): 1201-1210. 10.1007/s10457-013-9630-0

Vallejo VE, Roldan F, Dick RP. Soil enzymatic activities and microbial biomass in an integrated agroforestry chronosequence compared to monoculture and a native forest of Colombia. Biology and Fertility of Soils 2010; 46(6): 577-587. 10.1007/s00374-010-0466-8

Vidican R, Stoian V. Enzyme activity - indicator of soil biological dynamics. ProEnvironment 2015; 8(24): 553-558.

Wilson GWT, Rice CW, Rillig MC, Springer A, Hartnett DC. Soil aggregation and carbon sequestration are tightly correlated with the abundance of arbuscular mycorrhizal fungi: results from long-term field experiments. Ecology Letters 2009; 12(5): 452-461. 10.1111/j.1461-0248.2009.01303.x

Wright SF, Franke-Snyder M, Morton JB, Upadhyaya A. Timecourse study and partial characterization of a protein on hyphae of arbuscular mycorrhizal fungi during active colonization of roots. Plant Soil 1996; 181(2): 193-203. 10.1007/BF00012053

Wright SF, Upadhyaya A. A survey of soils for aggregate stability and glomalin, a glycoprotein produced by hyphae of arbuscular mycorrhizal fungi. Plant and Soil 1998; 198(1): 97-107. 10.1023/A:1004347701584

Wu QS, He XH, Zou YN, He KP, Sun YH, Cao MQ. Spatial distribution of glomalin-related soil protein and its relationships with root mycorrhization, soil aggregates, carbohydrates, activity of protease and $\beta$-glucosidase in the rhizosphere of Citrus unshiu. Soil Biology and Biochemistry 2012; 45: 181-183. 10.1016/j.soilbio.2011.10.002

Yeomans JC, Bremner JM. A rapid and precise method for routine determination of organic carbon in soil. Comm. Soil Science Plant Analysis 1988; 19(13): 1467-1476. 10.1080/00103628809368027 